\title{
Slope stability assessment along the Haibat Sultan main road, Koya, Kurdistan
}

\author{
Hamed M. Jassim ${ }^{1}$, Sarkawt A. Saad ${ }^{2}$ \& Bahra Dh. Ghafour ${ }^{1}$ \\ ${ }^{1}$ Department of Geotechnical Engineering, Faculty of Engineering, \\ Koya University, Kurdistan Region of Iraq \\ ${ }^{2}$ Departmant of Civil Engineering, Faculty of Engineering, \\ Koya University, Kurdistan Region of Iraq
}

\begin{abstract}
Haibat Sultan road represents one of the main and most important links between the two main cities in the Kurdistan region, namely Erbil and Sulaimaniya, passing through Koya city. It goes through two of the tourism and resort places, Kosar Resort Compound on the south western flank and Chenarock resort on the north eastern flank of the mountain series. The strategic importance of this road necessitates the appraisal of the driving safety on this road in order to secure a safe driving environment along it.

Throughout the history of this road, many incidents of dangerous rock falls and landslides have happened which have endangered the driving on it. In addition to these problems, a big danger exists regarding the existing trees which have been affected by these slides and failures leaving a big negative impact on the environment and the greens zones in this area.

In spite of the closure for few months during last spring and summer in order to do some maintenance works on this road, we still think that a big element of danger and unsafety still exists. This has motivated us to do some assessment of the slope stability through examining 14 stations along this road where we have tried to assess the stability of slopes and evaluate the existing dangers at these stations through photographic documentation, personal inspections and onsite observations. We have also tried to suggest some remedies and solutions to these problems and risks. This work was finalised with some suitable conclusions and relevant recommendations.
\end{abstract}

Keywords: slump failure, rotational sliding, disintegration, rock bolts, wire mesh, shotcrete. 


\section{Location}

Haibat Sultan Mountain is situated between the lowest mountains at the south and the highest mountains at the north of the Iraqi Kurdistan region. It extends from NW to SE which has an elevation of about $1200 \mathrm{~m}$ above sea level and $440 \mathrm{~m}$ with respect to the adjacent Koya plains. It is also one of the main natural sectors among Kirkuk, Erbil, Koya, Sulaimania and nearby villages and towns (Figs 1 and 2).The present road crossing Haibat Sultan Area represents a winding and curly state road with possible failures and rock falls along the road cut slopes, especially at the bedding planes at the southwestern side of the Mountain which has more possibility for sliding [3]. These failures resulted in repeated closure of the road for hours, sometimes days, leading to major traffic jams and affecting road-based traffic.

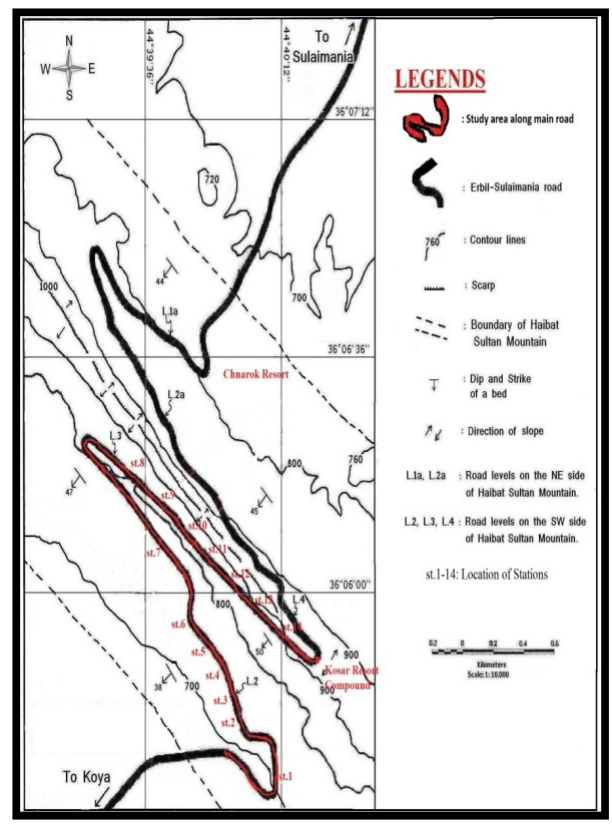

Figure 1: Location of stations and simplified topographic map of the study area.

\section{Stratigraphy of the study area}

\subsection{Pilaspi formation (Upper Eocene)}

It forms continuous steep ridges at the crest of Haibat Sultan Mountain. The formation consists mainly of light grey and yellowish white colour, well-bedded 
and very hard limestone and dolostones. These rocks at the lower part of the formation are interbedded with light green, thinly bedded and very soft marlstone. Its maximum true thickness at the study; the nature of the problem.

\subsection{Fatha (Lower Fars) formation (Middle Miocene)}

It forms a continuous belt at the foot SW side of Haibat Sultan Mountain. The formation consists of cyclic deposits of Mudstones and Limestone), with gypsum beds in the lower cycles. Mudstones, reddish brown in color are soft and highly fractured which represent the main constituents of the formation. Limestone is light grey and brown in color, well bedded and hard. Some limestones are fossiliferous and cherty nodules, especially at the lowermost part of the formation. Also gradual changes of marl to marly limestone occur at the middle of the formation. The maximum true thickness of this formation at the study area is about $62 \mathrm{~m}$.

\section{Theoretical background about slope instability}

Slope failures are considered as widespread natural hazardous phenomena on Earth. A slope's stability is a function of the material properties and geometry of the slope. The temporary instability of superficial mass of soil and rock, consolidated or unconsolidated is naturally occurring phenomena which has always been an acute problem. Human land-use does have major impacts on slope processes. The combination of uncontrollable natural conditions and artificially altered landforms can result in disastrous slope failures, then the downward movement of these superficial masses causing variety of phenomena and instability.

\subsection{Modes of failure in slopes}

Many classifications have been suggested for modes of failures in slopes. This is attributed to a number of factors which can be differentiated on various bases as mentioned in $[1,2,4,5]$.

This research, has concentrated a lot on the main modes of failure and much more on the modes of failure that were found in the study area, to establish best understanding of these failure modes.

\subsubsection{Plane sliding}

It is the down slope shear movement of coherent earth material on a single surface. The plane on which sliding occurs must strike parallel or nearly parallel (within approximately $\pm 20^{\circ}$ ) to the slope face. The sliding plane must daylight on the slope face, which means that the dip of the plane ( $\psi p)$ must be less than the dip of the slope face $(\psi f)$, [4], that is, $\psi p<\psi f$. The dip of the sliding plane ( $\psi \mathrm{p})$ must be greater than the angle of friction ( $\varnothing$ ) of this plane, that is, $\psi \mathrm{p}>\varnothing$ (Fig. 3). However, sometimes water pressure may cause a failure even though the dip of the sliding plane is less than the friction angle of the plane, by the activity of pore-water pressures. 

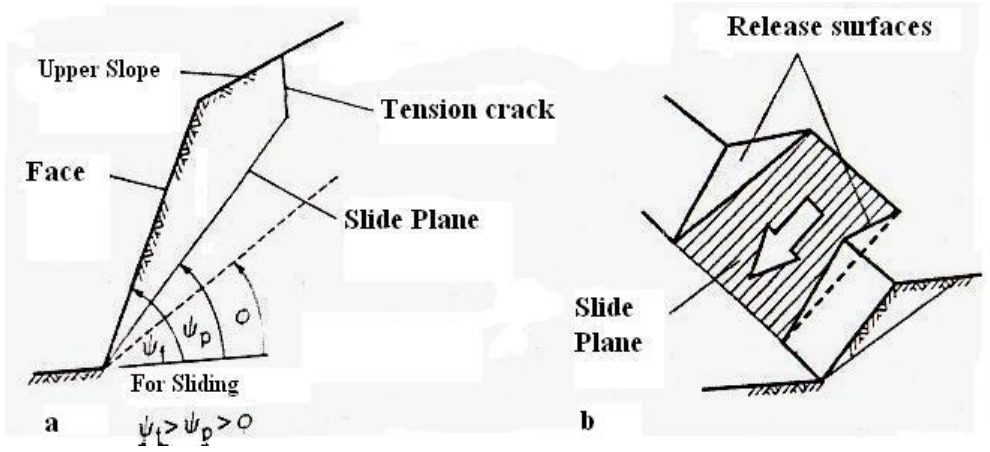

Figure 3: Plane sliding: (a) sketch for plane sliding where the release surfaces are clear (daylight slope); (b) cross section is drawn showing planes forming a plane failure (Wyllie and Mah 2004).

\subsubsection{Rotational sliding}

Rotational sliding involves sliding of materials on a single discontinuity surface curved concavely upward, which will tend to follow a circular failure path (Fig. 4(a)). It is formed in a soil or in highly fractured and weathered rocks as well as rocks with closely spaced, randomly oriented discontinuities [4]. The slumping involves the relative movement of rock units and/ or soils, where there are some unconsolidated or weak rock layers that travel as a unit to the down slope along a curved, concave upward failure surface, like a spoon (as shown in Fig. 4(b)). They occur where erosion has under-cut the slopes, heavy rains and earthquakes can trigger slumps.

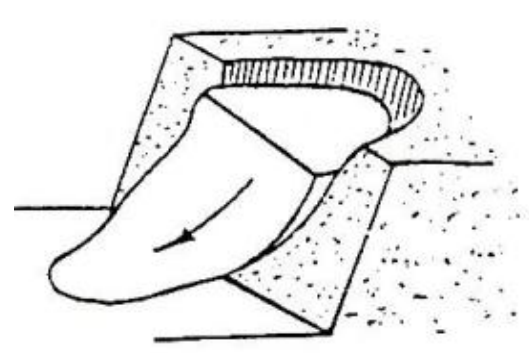

(a)

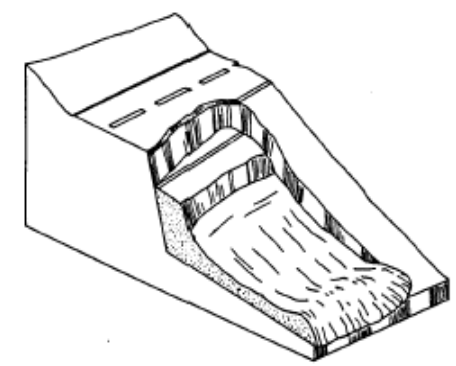

(b)

Figure 4: (a) A sketch showing rotational sliding; (b) a sketch showing slump failure.

\subsubsection{Rock fall}

Rock fall involves the free falling of an overhanging block from steep slopes by gravity action, the detached falling block that is mainly controlled by discontinuities results from disintegration and fracturing in rocks by the natural processes and/or by human activity (Fig. 5). 


\subsubsection{Disintegration}

It is a breakdown of rock masses into small pieces up to $10 \mathrm{~cm}$ diameter. The disintegration might result by weathering due to regularly repeated cycles of wetting, drying, and wide temperature variations. The disintegrated pieces are rolled on the slope faces and accumulated on the toe of the slope (Fig. 5).

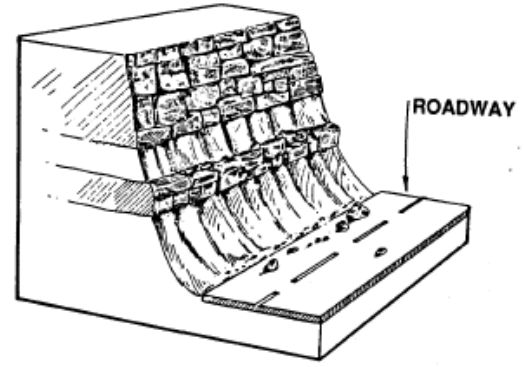

Figure 5: $\quad$ Rock fall failure.

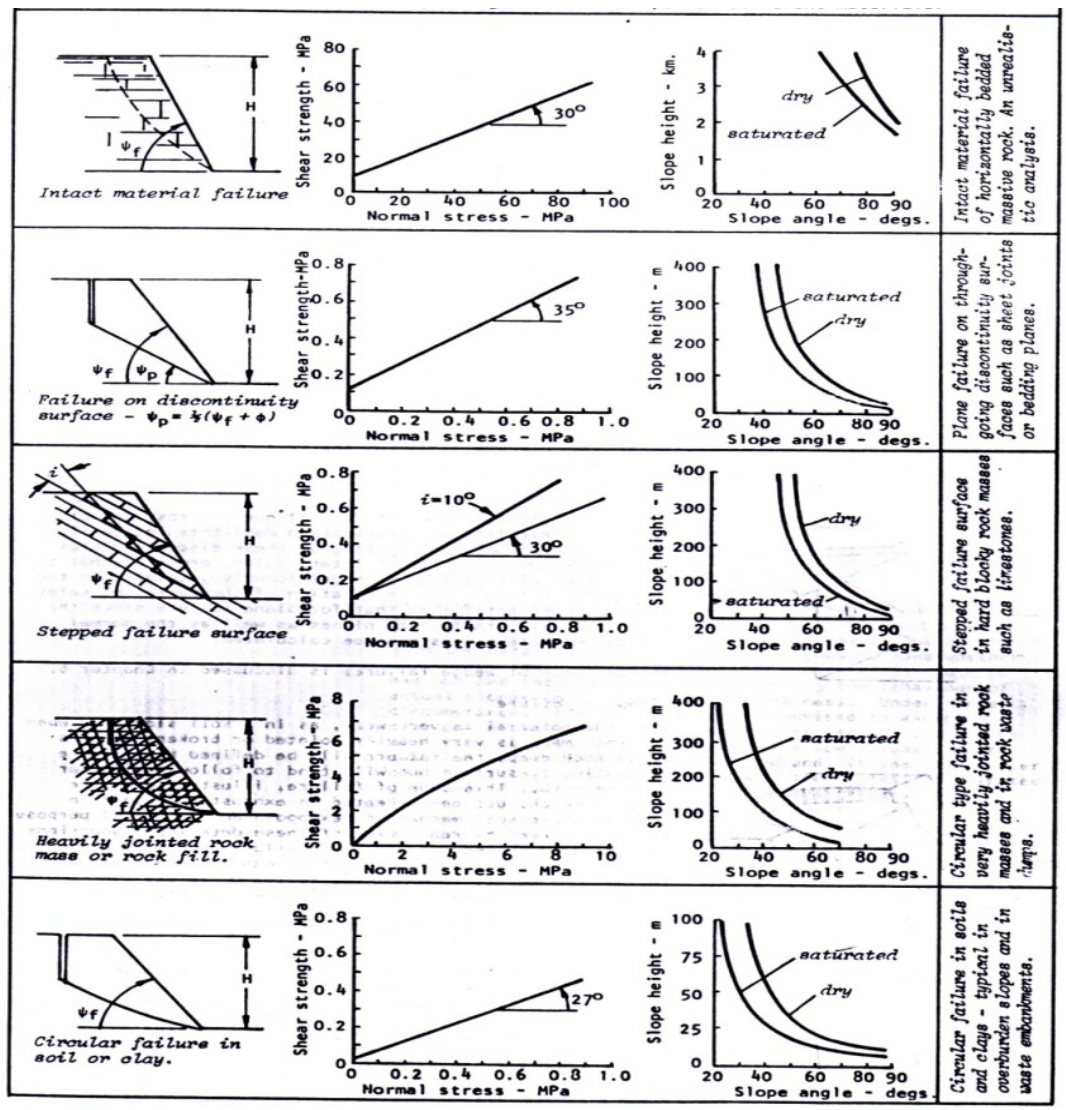

Figure 6: The relations between slope height and slope angle. 


\subsection{Critical slope height versus slope angle relationships}

Figure 6 helps for slope stability design and presents the relationships between the critical slope height and slope angle in the form of different graphs for various materials with different characteristics [4].

\section{The condition of stations}

The following section will give account on the conditions of the different stations which were selected along Haibat Sultan Road:

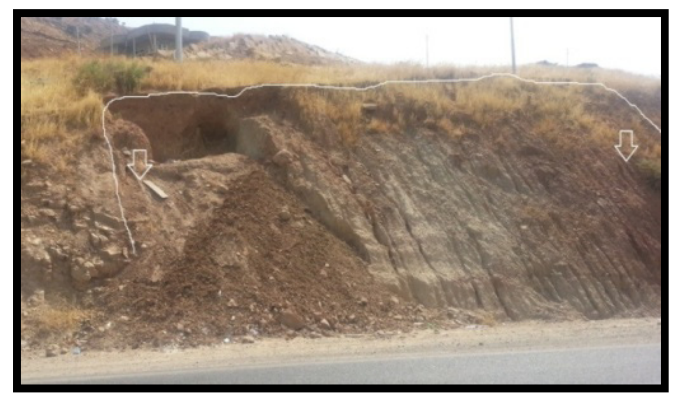

Figure 7: $\quad$ Station 1: This station is located $0.8 \mathrm{~km}$ from university gate on the Haibat Sultan main road (Figs 1 and 2), at an elevation of $699.3 \mathrm{~m}$ above mean sea level, within Fatha formation. The slope in this station is about $8 \mathrm{~m}$ high above its toe (main road), $30 \mathrm{~m}$ long along the road trend, and its attitude is $250 / 80^{\circ}$. Type of failure in this station is rotational sliding.

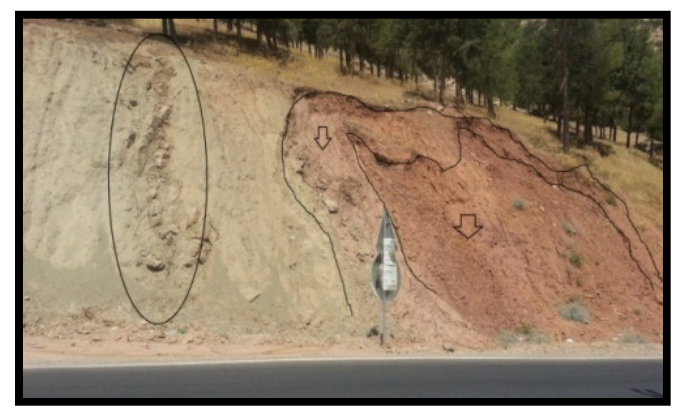

Figure 8: $\quad$ Station 2: This station is located $1 \mathrm{~km}$ from university gate on the Haibat Sultan main road (Figs 1 and 2), at an elevation of $712.7 \mathrm{~m}$ above mean sea level, within Fatha formation. The slope in this station is about $9 \mathrm{~m}$ high above its toe (main road), $35 \mathrm{~m}$ long along the road trend, and its attitude is $190 / 75^{\circ}$. Types of failure in this station are rotational sliding for clay stone bed and sandstone bed is disintegrated on the slope face. 


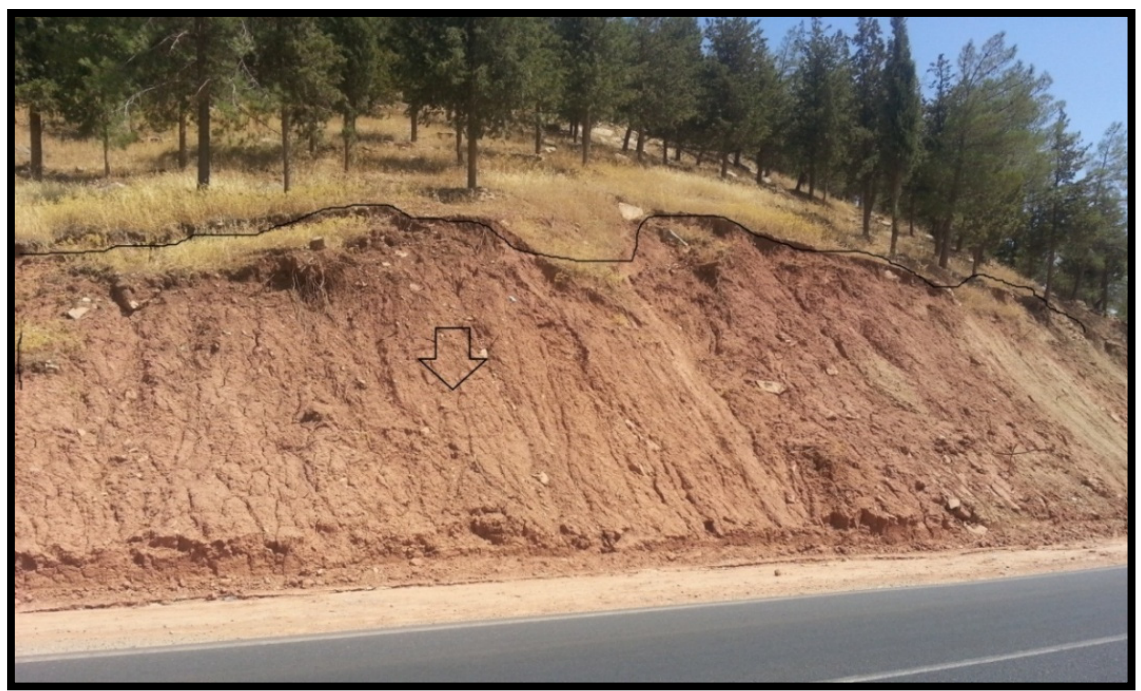

Figure 9: $\quad$ Station 3: This station is located $1.2 \mathrm{~km}$ from university gate on the Haibat Sultan main road (Figs 1 and 2), at an elevation of $735 \mathrm{~m}$ above mean sea level, within Fatha formation. The slope in this station about $7 \mathrm{~m}$ high above its toe (main road), $20 \mathrm{~m}$ long along the road trend, and its attitude is $241 / 70^{\circ}$. Type of failure in this station is rotational sliding of highly weathered claystone beds.
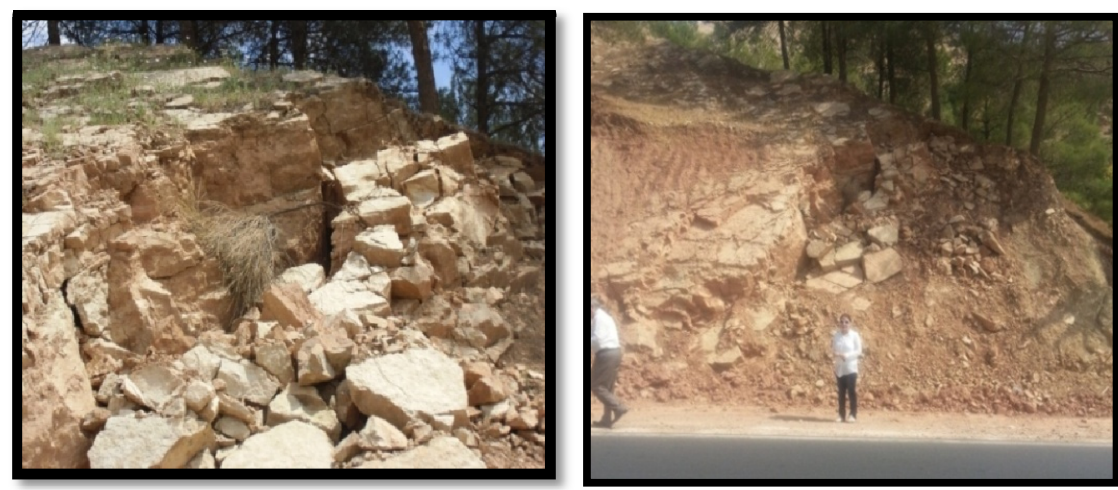

Figure 10: $\quad$ Station 4: This station is located $1.5 \mathrm{~km}$ from university gate on the Haibat Sultan main road (Figs 1 and 2), at an elevation of $738.6 \mathrm{~m}$ above mean sea level, within Fatha formation, The slope in this station is about $8 \mathrm{~m}$ high above its toe (main road), $20 \mathrm{~m}$ long along the road trend, and its attitude is 210/75 . Types of failures in this station are two types: circular sliding in the highly weathered clay stone strata, and disintegration of limestone beds and sliding on the slope face. 

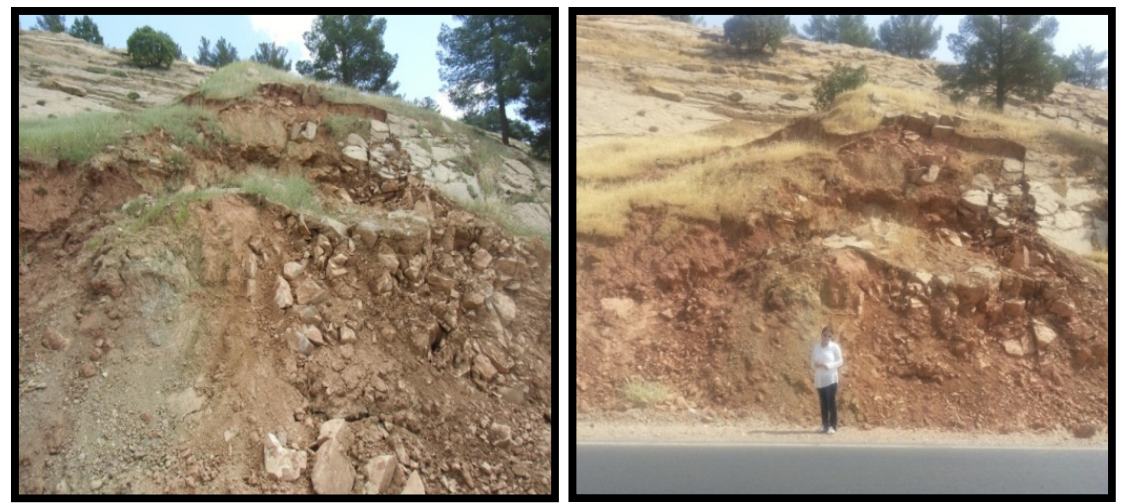

Figure 11: $\quad$ Station 5: This station is located $1.7 \mathrm{~km}$ from university gate on the Haibat Sultan main road (Figs 1 and 2), at an elevation of $747.2 \mathrm{~m}$ above mean sea level, within Fatha formation, The slope in this station is about $11 \mathrm{~m}$ high above its toe (main road), $20 \mathrm{~m}$ long along the road trend, and its attitude is $210 / 75^{\circ}$. The formation here consists of highly fractured and disintegrated limestone underlain by highly weathered clay stone strata experiencing a form of circular sliding.
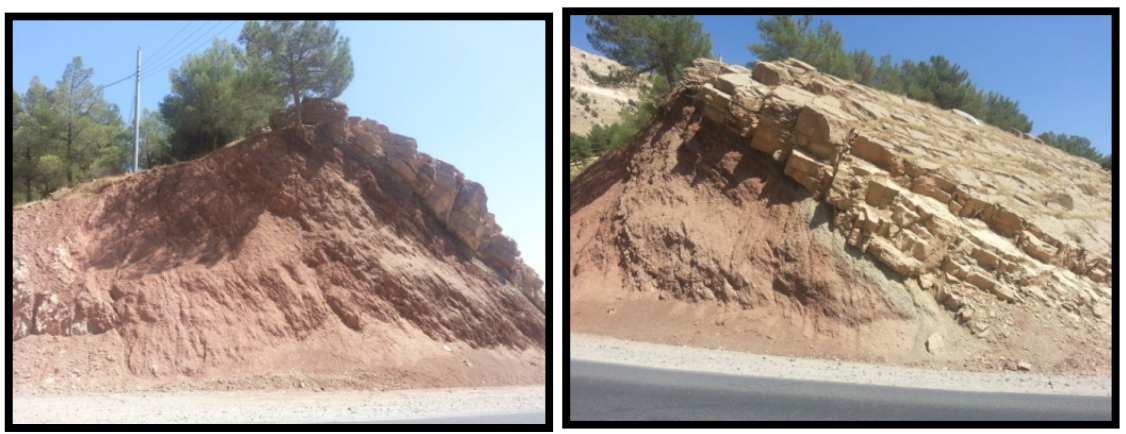

Figure 12: $\quad$ Station 6: This station is located $1.8 \mathrm{~km}$ from the university gate on the Haibat Sultan main road (Figs 1 and 2), at an elevation of $754.3 \mathrm{~m}$ above mean sea level, within Fatha formation, The slope in this station is about $12 \mathrm{~m}$ high above its toe (main road), $15 \mathrm{~m}$ long along the road trend and its attitude is 205/55'. Types of failure in this station are two risks of failure: the first is sliding of limestone blocks and second on the other side of slope, and due to differential weathering of the clay stone strata on the toe of the upper limestone beds, leading to toppling failure of the limestone blocks. 

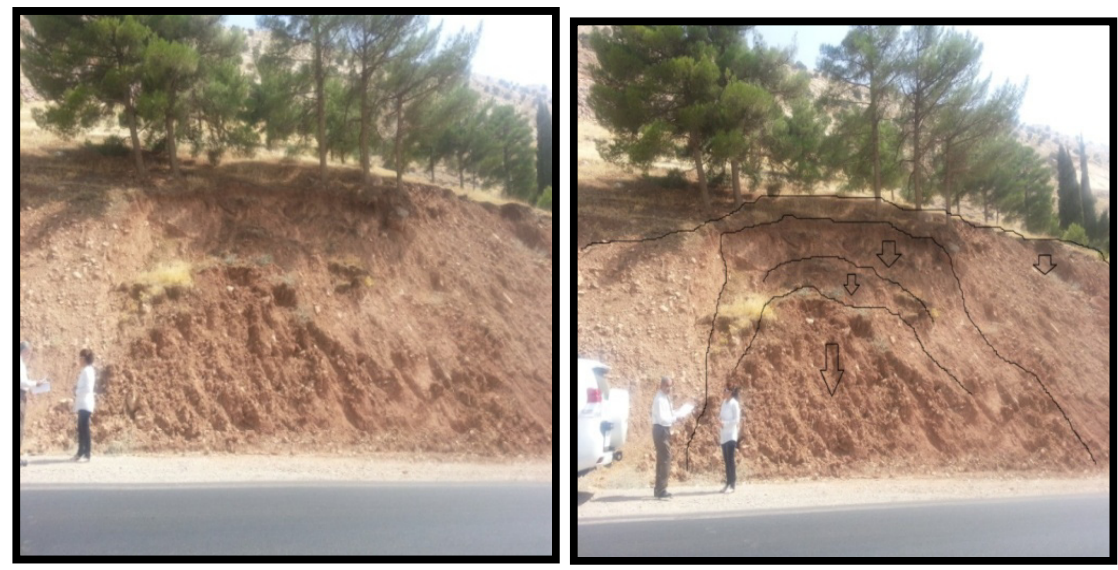

Figure 13: $\quad$ Station 7: This station is located $2.3 \mathrm{~km}$ from the university gate on the Haibat Sultan main road (Figs 1 and 2), at an elevation of $791.8 \mathrm{~m}$ above mean sea level, within Fatha formation, The slope in this station is about $8 \mathrm{~m}$ high above its toe (main road), $35 \mathrm{~m}$ long along the road trend, and its attitude is $215 / 70^{\circ}$. Types of failure in this station are successive rotational sliding of loose soil (highly weathered clay stone) forming slumping failure.
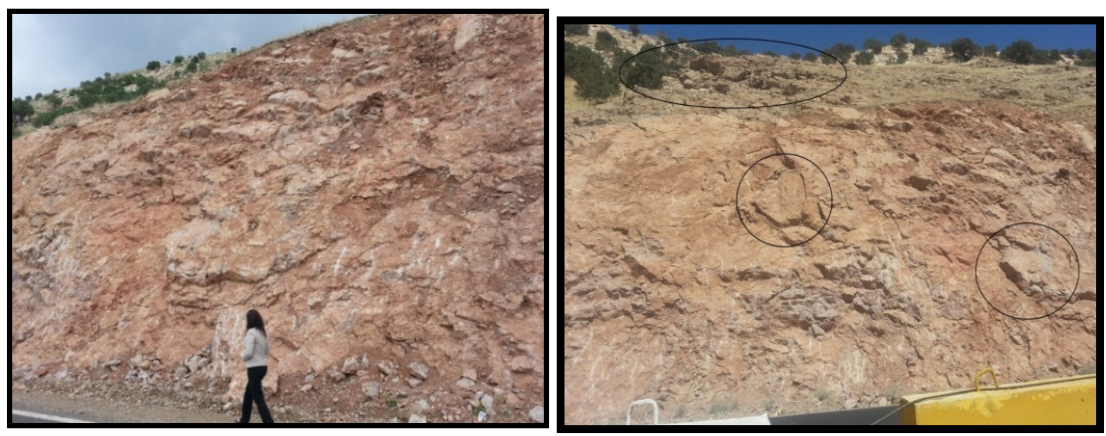

Figure 14: $\quad$ Station 8: This station is located $3.2 \mathrm{~km}$ from the university gate on the Haibat Sultan main road (Figs 1 and 2), at an elevation of $828.3 \mathrm{~m}$ above mean sea level, within Fatha formation, The slope in this station is about $35 \mathrm{~m}$ high above its toe (main road), $60 \mathrm{~m}$ long along the road trend and its attitude is $190 / 85^{\circ}$.The formation consists of limestone layer with clear jointing, very steep bedding producing risk of plane sliding and overhanging blocks on the top of slope representing potential failures. 

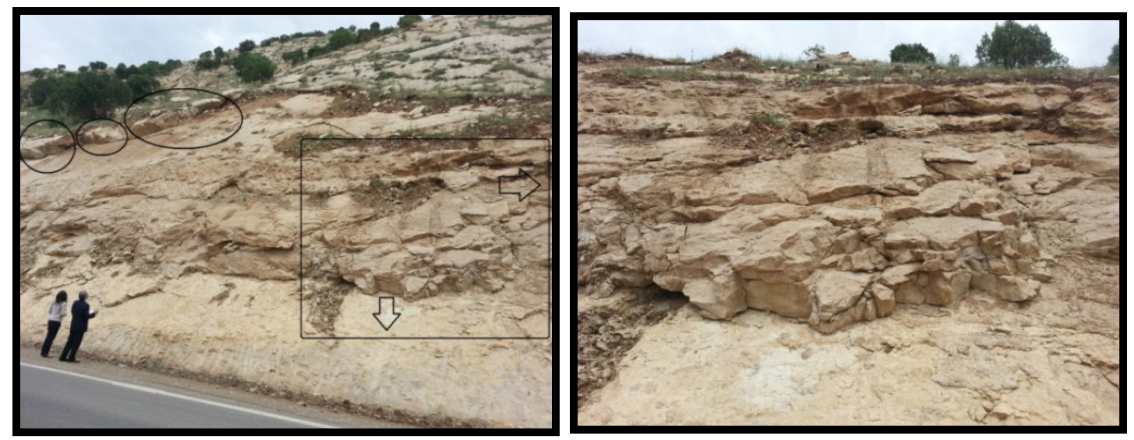

Figure 15: $\quad$ Station 9: This station is located $4.6 \mathrm{~km}$ from the university gate on the Haibat Sultan main road (Figs 1 and 2), at an elevation of $861.8 \mathrm{~m}$ above mean sea level, within Pilaspi formation. The slope in this station is about $70 \mathrm{~m}$ high above its toe (main road), $50 \mathrm{~m}$ long along the road trend, and its attitude is $210 / 70^{\circ}$. The slope consists of very thick layer of limestone with clear jointing and very steep bedding producing risk of plain sliding, and the presence of some overhanging large blocks of limestone on the top of slope representing a potential failure that may cause damage to the road and passengers.
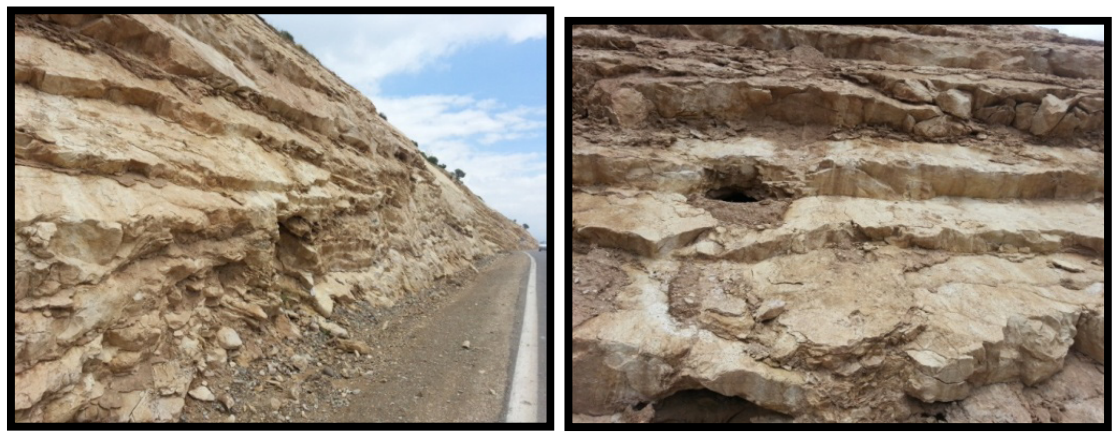

Figure 16: $\quad$ Station 10: This station is located $4.8 \mathrm{~km}$ from the university gate on the Haibat Sultan main road (Figs 1 and 2), at an elevation of $868.2 \mathrm{~m}$ above mean sea level, within Pilaspi formation. The slope in this station is about $70 \mathrm{~m}$ high above its toe (main road), $150 \mathrm{~m}$ long along the road trend, and its attitude is 201/81 . The slope consists of limestone layers with clear jointing and very steep bedding producing risk of plane sliding, and presence of some caves in the limestone beds appearing on the slope face. 


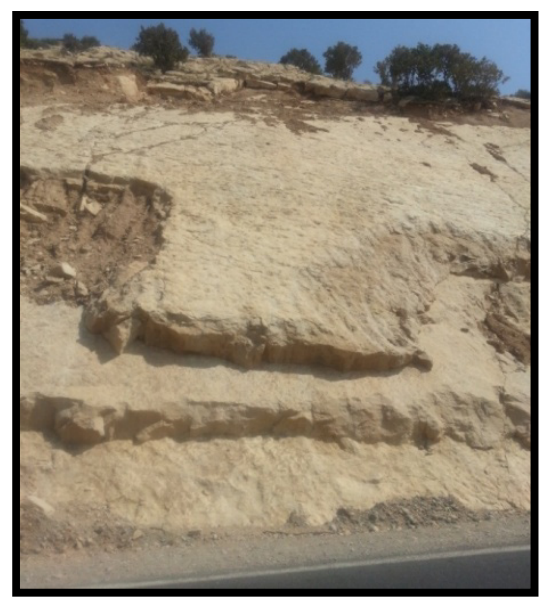

Figure 17: $\quad$ Station 11: This station is located $4 \mathrm{~km}$ from the university gate on the Haibat Sultan main road (Figs 1 and 2), at an elevation of $888.8 \mathrm{~m}$ above mean sea level, within Pilaspi formation. The slope in this station is about $100 \mathrm{~m}$ high above its toe (main road), $50 \mathrm{~m}$ long along the road trend, and its attitude is $215 / 75^{\circ}$. The failure in this station is plane sliding of steeply dipping layers of limestone which are cut by several sets of joints, and the presence of overhanging blocks on the top of the slope representing a potential failure.

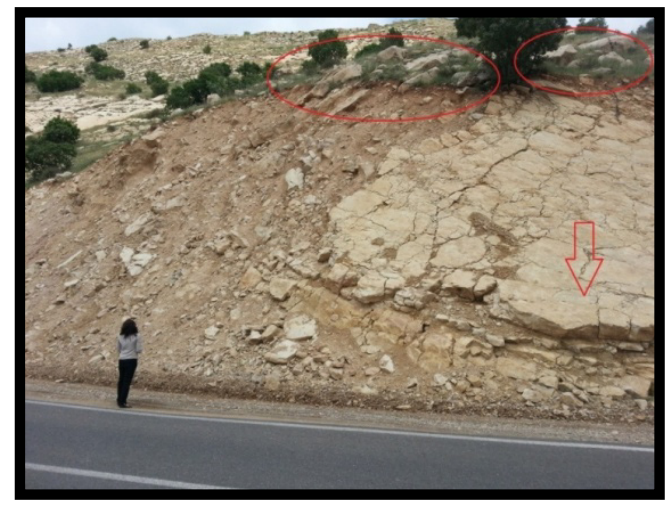

Figure 18: $\quad$ Station 12: This station is located $4.2 \mathrm{~km}$ from the university gate on the Haibat Sultan main road (Figs 1 and 2), at an elevation of $894.3 \mathrm{~m}$ above mean sea level, within Pilaspi formation. The slope in this station is about $20 \mathrm{~m}$ high above its toe (main road), $30 \mathrm{~m}$ long along the road trend, and its attitude is N20E/55'. Dipping beds of limestone which are parallel to slope face intersected by perpendicular joint set giving reason for a potential plane sliding towards the slope face, and also overhanging blocks on the top of the slope representing a potential failure. 


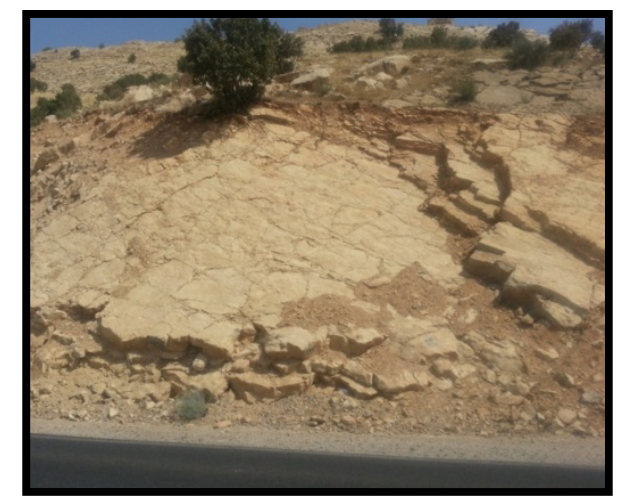

Figure 19: $\quad$ Station 13: This station is located $4.3 \mathrm{~km}$ from the university gate on the Haibat Sultan main road (Figs 1 and 2), at an elevation of $896.1 \mathrm{~m}$ above mean sea level, within Pilaspi formation. The slope in this station is about $100 \mathrm{~m}$ high above its toe (main road), $20 \mathrm{~m}$ long along the road trend, and its attitude is $190 / 55^{\circ}$. Dipping beds of limestone parallel to slope face intersected by multiple sets of joints defining many rock blocks which are imminent to plane sliding, and also isolated rock blocks about to fall at top of slope.

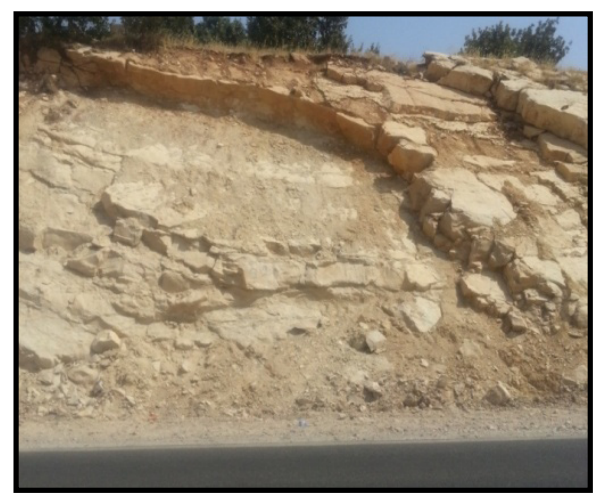

Figure 20: $\quad$ Station 14: This station is located $4.4 \mathrm{~km}$ from the university gate on the Haibat Sultan main road (Figs 1 and 2), at an elevation of $913.2 \mathrm{~m}$ above mean sea level, within Pilaspi formation. The slope in this station is about $15 \mathrm{~m}$ high above its toe (main road), $40 \mathrm{~m}$ long along the road trend, and its attitude is $\mathrm{N} 37 \mathrm{E} / 60^{\circ}$. Disintegrated limestone beds intersected by several sets of joints inter-bedded with thin layer of clay which makes the sliding of limestone blocks on top layer very imminent to failure. At top of slope are large blocks which are dangerously standing and about to fall. 


\section{Conclusions}

1 The investigated 14 stations along Haibat Sultan main road indicate that there are different rock slides and failures which have occurred in a previous time.

2 In addition to these failures, it is anticipated that there is a high probability for different rock slides, failures and rock falls to happen.

3 The evaluation of slope stability along this road reveals that driving along this road is unsafe before doing some considerable reinforcement and slope maintenance.

4 Various reinforcement measures have to be undertaken on this slope, such as rock bolting, installing wire mesh and shotcreting in order to reduce the risks of slope failures and rock falls.

5 The previous maintenance works which were made few months ago seem to be only cosmetically done and didn't help a lot to prevent the slope failures and rock falls to occur along this road.

6 The inter-bedding of successive dipping beds of limestone with thin mud stone layers will increase the risk of failures and rock slides, especially during rainy seasons.

\section{Recommendations}

1 It is necessary to complete the slope stability assessment study on the second part of the road extending on the north eastern flank of Haibat Sultan mountain (Chenarock side).

2 It is recommended to plant deep-rooted trees intensively in the clay and loose mud sites on the slope along this road in order to increase the stability and improve the environmental conditions in this area.

3 In addition to the support measures which were mentioned in the conclusions above, it is recommended to install a strong retaining wall to catch and prevent all sliding beds and rock falls from hindering the driving on this road.

4 It is recommended to install a systematic long rock bolts programme in the thickly bedded limestone layers in order to increase the overall stability of the slope.

\section{References}

[1] Al-Saadi, S.N, 1988, Modes of failure in the rock slopes of injana area, central Iraq, $1^{\text {st }}$ Proceedings of the International Symposium on the Geology of Deserts Environment, Baghdad, Vol. 1, pp. 227-245.

[2] Goodman, R.E. Bray, J.W. 1976, Toppling of rock slopes, Proc, Specialty Conf. on Rock Eng. for foundation and slopes, ASCE, Boulder, Colorado, Vol. 2, pp. 201-234. 
[3] Hamasur, Gh.A., 1991. Engineering - Geological study of rock slope stability in Haibat Sultan area, NE Iraq. Un pub. M.Sc. thesis, University of Salahaddin, Erbil, Iraq. 153p. (in Arabic)

[4] Hoek, E. \& Bray, J.W., 1981, Rock Slope Engineering, $3^{\text {rd }}$ ed., Institution of Mining and Metallurgy, London, 358p.

[5] Varnes, D.J., 1978 Slope movement type and processes; In Schuter, R.L. and Krizek, R.J., 1978 Landslide analysis and control. National Academy of Science, Washington, Special Report 176, pp. 12-33. 